\title{
Comparing the Biomass Yield and Biogas Potential of Phragmites australis with Miscanthus x giganteus and Panicum virgatum Grown in Canada
}

\author{
Kurtis Baute ${ }^{1}$, Laura L. Van Eerd ${ }^{1}$ (D), Darren E. Robinson ${ }^{2}$, Peter H. Sikkema ${ }^{2}$, \\ Maryam Mushtaq ${ }^{1}$ and Brandon H. Gilroyed ${ }^{1, *}$ (D) \\ 1 School of Environmental Sciences, University of Guelph Ridgetown Campus, 120 Main Street East, \\ Ridgetown, ON N0P 2C0, Canada; kurtis.baute@gmail.com (K.B.); lvaneerd@uoguelph.ca (L.L.V.E.); \\ mushtaq@uoguelph.ca (M.M.) \\ 2 Department of Plant Agriculture, University of Guelph Ridgetown Campus, 120 Main Street East, \\ Ridgetown, ON N0P 2C0, Canada; drobinso@uoguelph.ca (D.E.R.); psikkema@uoguelph.ca (P.H.S.) \\ * Correspondence: bgilroye@uoguelph.ca; Tel.: +1-519-674-1500 (ext. 63605)
}

Received: 28 June 2018; Accepted: 21 August 2018; Published: 22 August 2018

\begin{abstract}
The production of bioenergy from plant biomass has the potential to reduce fossil fuel use. The number of biogas facilities around the world has risen dramatically, increasing demand for feedstocks. In this study the invasive perennial grass Phragmites australis was evaluated as a biogas feedstock in comparison with Miscanthus x giganteus and Panicum virgatum. Results from three field sites for each species demonstrated that biomass yields for P. australis averaged approximately $1.82 \pm 0.9 \mathrm{~kg}$ dry matter $(\mathrm{DM}) \mathrm{m}^{-2}$, comparable to that of $M . \mathrm{x}$ giganteus. Yield of P. australis was greater than P. virgatum, which ranged from $0.49 \pm 0.06$ to $0.69 \pm 0.07 \mathrm{~kg} \mathrm{DM} \mathrm{m}^{-2}$ in July and October, respectively. In mesophilic bench-top digester experiments, methane yields were greater for July-harvested material than for October, ranging from $172.4 \pm 15.3$ to $229.8 \pm 15.2 \mathrm{~L} \mathrm{CH}_{4} \mathrm{~kg}^{-1}$ volatile solids (VS) for all perennial grasses. Methane yields per hectare were highest for October-harvested $M . \mathrm{x}$ giganteus, followed by July-harvested $M . \mathrm{x}$ giganteus and P. australis, whereas methane yield from $P$. virgatum at both harvest times was lower than the other two species. These results suggest that $P$. australis is not an economically viable biogas feedstock without pre-treatment to improve methane yield.
\end{abstract}

Keywords: anaerobic digestion; common reed; methane; perennial grass; switchgrass

\section{Introduction}

The number of biogas facilities in Canada and around the world is rapidly increasing, with the majority of Canadian biogas plants being commissioned in the last 10 years [1,2]. As the industry continues to grow, so does the demand for sustainable, reliable, and affordable feedstocks with high methane yields. Internationally, energy crops are currently used as biogas co-substrates, with 0.5 million hectares of biogas maize grown in Germany alone [3]. The use of energy crops in anaerobic digestion can improve biogas yields, provide a reliable and consistent feedstock supply, and overcome some of the limitations of mono-digestion by improving the $\mathrm{C}: \mathrm{N}$ ratio and buffering capacity [4]. While using annual crops like maize for biogas production is viable in some regions, perennial crop species may be better suited for biogas utilization in others. Perennial grass species can be harvested for many years after planting, due to their root masses, which store nutrients from year to year.

There has been considerable scientific research on the use of perennial grass species as feedstocks for use in anaerobic digestion, including the publication of over 30 peer-reviewed articles since 2000. 
Although dozens of grass species have been screened for suitability in different climates around the world, three perennial grasses have been the focus of research in North America: Panicum virgatum (switchgrass) [5,6], Miscanthus spp. (miscanthus) [7] and Phalaris arundinacea (reed canarygrass) [8]. However, other perennial grass species merit consideration as feedstocks for anaerobic digestion in North America as well.

Phragmites australis (Cav.) Trin. ex. Steud. (common reed) is an invasive perennial grass species in North America which is frequently found in the Great Lakes region, including more than 24,600 hectares of monocultural stands mapped along the American side of the Lakes alone [9]. This species has traditionally been harvested for use in thatched roofs and biomaterials in Eastern Europe and Africa, having an estimated market value of approximately $\$ U S 45,000 \mathrm{ha}^{-1}$ in Botswana [10]. In North America, P. australis is not utilized as a commodity, and it is the focus of control and eradication efforts, due to its negative ecological impact, particularly in wetlands. Current eradication strategies in Ontario often consist of (1) glyphosate application, followed by (2) mechanically rolling dead biomass, and (3) culminating with prescribed burning. While effective, this strategy is expensive, time consuming, and not applicable to stands occurring in standing water. Harvesting P. australis biomass for use as a feedstock in anaerobic digestion could potentially assist with eradication efforts by providing a monetary incentive for biomass removal. Further, removal of nutrients (e.g., N, P, K) contained in P. australis biomass from wetland areas experiencing eutrophication pressure from excessive nutrient runoff would be beneficial for ecosystem restoration.

The same traits that make $P$. australis invasive, such as perennial regrowth from rhizomes, the ability to spread from seeds, growth on marginal lands, the ability to outcompete many other plant species, and having few pests, makes it attractive as a source of biomass [11]. However, reported biomass yields for P. australis vary considerably, based on location, ranging from $0.3 \mathrm{~kg}$ dry matter $(\mathrm{DM}) \mathrm{m}^{-2}$ from a site in Sweden, to $0.7 \mathrm{~kg} \mathrm{DM} \mathrm{m}^{-2}$ in the British Isles [12], to $1.5 \mathrm{~kg} \mathrm{DM} \mathrm{m}^{-2}$ in the Netherlands [13], to $4.2 \mathrm{~kg} \mathrm{DM} \mathrm{m}^{-2}$ in Romania [14]. In one experiment in Scotland, yields varied considerably between three sites in the same region, ranging from 0.7 to $4.0 \mathrm{~kg} \mathrm{DM} \mathrm{m}^{-2}$ [15]. However, research on both the use of $P$. australis for biogas and on its above-ground biomass yields in North America is lacking. Considering the variability in P. australis biomass, there is a need to determine the productivity of North American P. australis stands.

Laboratory-scale experiments suggest that $P$. australis may potentially be a suitable co-substrate for anaerobic digestion, producing $220 \mathrm{~L} \mathrm{CH}_{4} \mathrm{~kg}^{-1}$ volatile solids (VS) in one study [16]. Results from a Swedish study which calculated efficiency costs including harvest, transport, storage, and treatment, concluded that there was an energy output of $4.36 \mathrm{MJ} \mathrm{kg}^{-1} \mathrm{DM}$ using anaerobic digestion [17]. Phragmites australis has also been chosen for research as a co-substrate for its ability to improve the C:N ratio during anaerobic digestion [4]. However, a Swedish study evaluating the economics of using wild P. australis as a biogas feedstock calculated a net loss of $\$ 720$ to 2400 (USD) per ha harvested [18]. This study did not include social and environmental benefits, such as carbon sequestration and water remediation, as others have done in their calculations [14,19]. There is a need to evaluate the biogas potential of $P$. australis biomass under North American conditions, including biomass productivity, harvest timing and frequency, and methane potential.

The overall objective of our study was to determine the feasibility of using wild harvested stands of $P$. australis as a feedstock for anaerobic digestion in Canada. The specific objectives of our study were: (1) to quantify the amount of $P$. australis biomass produced in wild stands at two harvest times in Southwestern Ontario in comparison to two perennial biomass crops (M. x giganteus and P. virgatum); (2) to determine the biogas potential of P. australis, M. x giganteus, and P. virgatum in comparison to Zea mays L. silage; and (3) to calculate biogas yields per unit area for each species tested. 


\section{Materials and Methods}

\subsection{Site History and Field Sampling}

To assess the biomass and biogas potential of P. australis in Southwestern Ontario, three wild stands were selected and compared to three cultivated fields of the biomass crops Miscanthus x giganteus Greef \& Deuter ex Hodkinson \& Renvoize cultivar 'Nagara' (miscanthus), and the P. virgatum L. cultivar 'Cave-in-Rock' (switchgrass) (Figure S1). All cultivated fields had reached stand maturity, with establishment occurring at least three years prior to the beginning of this study. After establishment, P. virgatum and M. x giganteus crops received no fertilizer or pesticide inputs. All M. x giganteus sites were left to over-winter in the field, and were harvested annually in the spring, whereas P. virgatum sites were either fall-harvested or not harvested as permanent prairie. Phragmites australis sites were selected from wild invasive stands that were not maintained or harvested, though natural burning events had occurred previously at two of the sites. Selected P. australis sites were absent of the native $P$. australis phenotype, typically non-flooded, and preference was given to larger sites with a low likelihood of eradication during the two-year study. For biomass yield comparisons, whole-plant Z. mays silage was assumed to produce $1.85 \mathrm{~kg} \mathrm{DM} \mathrm{m}^{-2}$ [20].

In 2013 and 2014, all sites were sampled in early July and mid-October. These sampling times were chosen in order to evaluate the biomass yield potential of $P$. australis that was harvested twice per year [21]. However, in 2013, no regrowth was observed after the July harvest, and multiple harvest strategies were not investigated in 2014.

At each site and time point, plant samples were harvested using a $1 \mathrm{~m}^{2}$ quadrat placed randomly at distances $>3 \mathrm{~m}$ from one another, from previous sample areas, and from the field edge $(n=3)$. The mean of three quadrats at each harvest time was used as the sample value for each site. Quadrats were assembled on the soil surface, and pruning shears were used to manually cut the biomass approximately $10 \mathrm{~cm}$ above ground level. At each harvest, fresh biomass yield was weighed (Active Scale 110; Ohaus Corporation, Parsipanny, NJ, USA) stems were counted, and their lengths were measured. A subsample was cut to $<25 \mathrm{~cm}$ segments, frozen, and stored at $-20{ }^{\circ} \mathrm{C}$ for the biological methane potential (BMP) experiments, and a second subsample was dried for $48 \mathrm{~h}$ at $60^{\circ} \mathrm{C}$ in a custom-built walk-in dryer. Subsample dry weight was recorded, and leaves were separated from stems at the ligule and weighed separately. Dried samples from July and October of 2013 were finely ground to a maximum particle size of $2 \mathrm{~mm}$ (Mill Model 4, Thomas Scientific, Swedesboro, NJ, USA) and sent to SGS Agrifood Laboratories Inc. (Guelph, ON, Canada) for constituent analysis via wet chemistry.

\subsection{Biological Methane Potential Assay}

Digestate used as seed for BMP assays was taken from a $250 \mathrm{~kW}$ commercial anaerobic digester (AD) at the University of Guelph Ridgetown Campus. Characteristics of the digester diet varied in each run (Table 1), which is typical of commercial-scale AD. The digestate was stored anaerobically at $38^{\circ} \mathrm{C}$ and agitated daily (for a duration of $\sim 1 \mathrm{~min}$ ) for three weeks prior to initiating each trial, in order to minimize background gas production from inoculum during the experiment.

A loading rate of 1:2 volatile solids (VS) ratio of substrate (grass biomass) to inoculum (digestate) was used [22]. Total solids (TS) and VS were determined gravimetrically after drying at $105^{\circ} \mathrm{C}$, and subsequent combustion using a muffle furnace (Lindberg Blue $\mathrm{M}$, Thermo Scientific, Waltham, MA, USA) was performed according to standard methods [23].

Frozen grass samples were finely chopped to a target particle size of $1 \mathrm{~cm}$ with scissors, and were mixed with digestate to a working volume of $400 \mathrm{~mL}$ in $500 \mathrm{~mL}$ glass media bottles. The $\mathrm{pH}$ of the contents of each bottle was recorded before and after the experiment using a Seven Excellence $\mathrm{pH}$ meter (Mettler Toledo, Switzerland).

After preliminary analysis of biomass yield (DM) revealed no significant differences between sites $(p>0.05)$, harvest material from a single site location was randomly chosen for BMP analysis. 
A completely randomized block design was utilized with three runs; each run included material from all plant species at both harvest time-points from the 2013 sampling year ( $n=6$ bottles). Samples from 2014 were not assessed for BMP due to time constraints and a general lack of year effect or interactions on biomass fresh matter (FM) or DM yield. In addition, three bottles containing corn silage were included in each run to assess intra-run variability, and a digestate-only control bottle was included to measure residual gas production from the inoculum, resulting in 10 total samples per run.

The bottles were kept at $38^{\circ} \mathrm{C}$ in a BioProcess AMPTS II (Lund, Sweden) water-bath, and were mechanically stirred, using electric motors on a timer, for $60 \mathrm{~s}(160 \mathrm{rpm})$, followed by $60 \mathrm{~s}$ without stirring, for the duration of the experiment. Individual bottle headspaces were flushed with nitrogen gas after being sealed, in order to promote anaerobic conditions. The biogas produced was directed through $\mathrm{CO}_{2}$-fixation bottles, and methane production was measured continually via liquid displacement and buoyancy using an AMPTS II BioProcess flow cell array and data acquisition unit. On a weekly basis, $1 \mathrm{~mL}$ gas samples were taken from the headspace of each bottle via syringe at a septa port. Gas samples were immediately assessed for biogas composition using an SRI 8610C gas chromatograph equipped with a $1.83 \mathrm{~m} \times 3.18 \mathrm{~mm}$ stainless steel molecular sieve $13 \times$ packed column (SRI Instruments, Torrance, CA, USA), and a thermal conductivity detector set at $150{ }^{\circ} \mathrm{C}$. Oven temperature was kept at $40{ }^{\circ} \mathrm{C}$ during $11 \mathrm{~min}$ assessment, with helium as a carrier gas at a flow-rate of $20 \mathrm{~mL} \mathrm{~min}^{-1}$.

Table 1. Operating conditions of the $250 \mathrm{~kW}$ commercial-scale anaerobic digester that inoculum was retrieved from for each experimental run, as well as characteristics of the digestate used for biological methane potential assays. Values represent means \pm standard deviation.

\begin{tabular}{cc}
\hline Variable & Value \\
\hline Operating Temperature $\left({ }^{\circ} \mathrm{C}\right)$ & $38.2 \pm 0.3$ \\
Retention Time $(\mathrm{d})$ & $52.8 \pm 11$ \\
Diet Components $(\mathrm{kg}):$ & \\
Dairy Manure & $24,475 \pm 5875$ \\
Corn Silage & $188 \pm 135$ \\
Fats, Oils, and Grease & $795 \pm 214$ \\
Total & $25,458 \pm 5922$ \\
Total Solids $(\%)$ & $1.59 \pm 0.15$ \\
Volatile Solids $(\%)$ & $55.34 \pm 4.51$ \\
pH & $8.05 \pm 0.07$ \\
Electrical Conductivity (mmhos cm $\left.{ }^{-1}\right)$ & $16.55 \pm 0.82$ \\
Chemical Composition: & \\
$\mathrm{N}(\%)$ & $0.19 \pm 0.06$ \\
$\mathrm{P}(\%)$ & $0.02 \pm 0.01$ \\
$\mathrm{~K}(\%)$ & $0.18 \pm 0.01$ \\
$\mathrm{NH}_{3}\left(\mathrm{mg} \mathrm{kg}^{-1}\right.$ dry matter $)$ & $1660 \pm 115$ \\
\hline
\end{tabular}

Each experiment ran for 21 days, at which point $>90 \%$ of gas production was likely to have occurred [24]. After digestion, subsamples of digestate were frozen and sent to SGS Agrifood Laboratories (Guelph, ON, Canada) for constituent analysis, and TS and VS contents were determined. Digestion of grass biomass was determined by calculating the difference between preand post-digestion values for TS and VS.

\subsection{Statistical Methods}

Data were analyzed using SPSS Statistics (Version 21), with an error rate set as 0.05 . For the field study, the independent variables were: species (fixed), harvest time (fixed), year (fixed), field site (random), and interactions thereof. Dependent variables were: fresh matter (FM) yield, dry matter (DM) yield, shoot height, stems per $\mathrm{m}^{-2}$, percent leaf matter, and chemical components. Data were tested for normality, independent error, homogeneity, and outliers with Grubbs' test. Data that did 
not meet the assumptions were transformed using either square root or base-10 logarithmic, and back-transformed for presentation of results. Four-way analysis of variance (ANOVA) was used to assess each dependent variable against site, year, species, and harvest time. Tukey's range tests were conducted to assess the effect of harvest timing.

For the BMP experiment, the independent variables species and harvest time were treated as fixed effects, the run was treated as a random effect, and the dependent variables were methane yield, percent methane, and VS reduction. Interactions for harvest time by species, harvest time by run, and run by species were also tested. Data were tested for normality, heterogeneity of error, and independent error. A one-way ANOVA was conducted on the triplicate values of $Z$. mays with $\mathrm{L}$ $\mathrm{CH}_{4} \mathrm{~kg}^{-1} \mathrm{VS}$ as the dependent variable and the run as the independent variable. A two-way ANOVA was conducted to evaluate perennial grass species methane yields vs harvest time. Tukey's range tests were calculated for all treatments.

\section{Results}

\subsection{Biomass Yield and Chemical Composition}

A three-way ANOVA on the field data showed no year effect for FM or DM biomass yield or other characteristics (data not shown). Dry matter yields for M. $\mathrm{x}$ giganteus and P. australis were not statistically different, whereas $P$. virgatum had lower yields (Table 2). Dry matter percentage for $M . \mathrm{x}$ giganteus, increased when the harvest was delayed from July to October but not for P. virgatum or $P$. australis (Table 2). Fresh matter yields were different for each species, where M. $\mathrm{x}$ giganteus had the highest yield, followed by P. australis and P. virgatum (Table 3).

Table 2. Mean ( \pm standard error) composition of 2013 samples of Phragmites australis, Panicum virgatum, and Miscanthus x giganteus $(n=3)$; and Zea mays silage $(n=1)$. Means followed by the same letter in each column were not significantly different according to Tukey's range test $(p>0.05)$. Zea mays was not analyzed due to lack of replication.

\begin{tabular}{|c|c|c|c|c|c|}
\hline Species and Harvest Time & Dry Matter & Cellulose & Hemicellulose & Lignin & Protein \\
\hline & $-\ldots \%-\ldots$ & $\ldots-\ldots$ & - $\mathrm{g} \mathrm{kg}^{-}$ & $\mathrm{DM}^{+} \ldots \ldots$ & \\
\hline \multicolumn{6}{|l|}{ Species } \\
\hline M. x giganteus & $46.5( \pm 2.9) b$ & $360( \pm 7.7)$ & $267.9( \pm 3.9) b$ & $74.8( \pm 20.7)$ & $79.2( \pm 15.2) b$ \\
\hline P. australis & $37.2( \pm 4.1) \mathrm{a}$ & $374.5( \pm 9.6)$ & $245.2( \pm 3.6) \mathrm{a}$ & $108.0( \pm 5.9)$ & $88.9( \pm 11.7) b$ \\
\hline P. virgatum & $35.1( \pm 5.4) \mathrm{a}$ & $360.9( \pm 4.9)$ & $274.6( \pm 3.3) b$ & $67.4( \pm 4.7)$ & $43.8( \pm 4.9) \mathrm{a}$ \\
\hline Z. mays & 29.3 & 205.4 & 175.9 & 63.6 & 83 \\
\hline \multicolumn{6}{|l|}{ Harvest Time } \\
\hline July & $31.5( \pm 2.5) \mathrm{m}$ & $367.4( \pm 8.6)$ & $262.7( \pm 4)$ & $77.8( \pm 14.7)$ & $90.8( \pm 11.2) \mathrm{m}$ \\
\hline October & $47.7( \pm 2.5) n$ & $362.9( \pm 2.9)$ & $262.4( \pm 6.3)$ & $89( \pm 7.6)$ & $50.5( \pm 5.5) n$ \\
\hline \multicolumn{6}{|l|}{ Species * Harvest Time } \\
\hline M. $\mathrm{x}$ giganteus * July & $40.3( \pm 0.5)$ & $363.7( \pm 16.4)$ & $261.2( \pm 1.7) x y$ & $76.3( \pm 46.3)$ & $112.2( \pm 5.5) x$ \\
\hline M. $\mathrm{x}$ giganteus $*$ October & $52.8( \pm 1.6)$ & $356.3( \pm 3.7)$ & $274.7( \pm 5.2) x$ & $73.3( \pm 2.9)$ & $46.3( \pm 5.8) \mathrm{z}$ \\
\hline P. australis * July & $30.8( \pm 1.8)$ & $380.9( \pm 20.3)$ & $252( \pm 3.0) \mathrm{yz}$ & $98.5( \pm 7.2)$ & $108.6( \pm 16) x y$ \\
\hline P. australis * October & $43.6( \pm 6.2)$ & $368.1( \pm 3.5)$ & $238.4( \pm 2.9) \mathrm{z}$ & $117.6( \pm 5.6)$ & $69.2( \pm 6.4) \mathrm{yz}$ \\
\hline P. virgatum * July & $23.6( \pm 0.6)$ & $357.6( \pm 8.4)$ & $274.8( \pm 5.5) \times$ & $58.8( \pm 0.3)$ & $51.7( \pm 6.8) \mathrm{z}$ \\
\hline P. virgatum * October & $46.6( \pm 3.3)$ & $364.3( \pm 6.1)$ & $274.3( \pm 2.2) x$ & $76.1( \pm 0.8)$ & $36( \pm 2.7) z$ \\
\hline Effect & -..... & $-1-1$ & -- $p$ value -- & (n-.... & $\ldots \ldots$ \\
\hline Species & 0.006 & 0.408 & $<0.001$ & 0.126 & $<0.001$ \\
\hline Harvest Time & $<0.001$ & 0.645 & 0.948 & 0.496 & $<0.001$ \\
\hline Harvest Time * Species & 0.185 & 0.697 & 0.021 & 0.823 & 0.034 \\
\hline
\end{tabular}

${ }^{\dagger}$ DM: dry matter. ${ }^{*}$ Denotes interaction between variables. 
Table 3. Mean ( \pm standard error) plant characteristics for year by species interactions for Phragmites australis, Panicum virgatum, and Miscanthus x giganteus 'Nagara', at three sites in Southwestern Ontario, Canada, harvested in 2013 and $2014(n=6)$. Means followed by the same letter in each column are not significantly different according to Tukey's range test $(p>0.05)$. Other results of the three-way analysis of variance (ANOVA) shown in Table 4.

\begin{tabular}{|c|c|c|c|c|c|}
\hline Species and Harvest Time & Fresh Matter Yield & Dry Matter Yield & Stems & Height & Leaf \\
\hline & \multicolumn{2}{|c|}{$\ldots \ldots \mathrm{kg} \mathrm{m}^{-2} \ldots \ldots$} & - - Number $\mathrm{m}^{-2}$ _- & $---\mathrm{cm}--$. & $\%$ of Total DM \\
\hline \multicolumn{6}{|l|}{ Species* Year } \\
\hline M. x giganteus $* 2014$ & $4.6( \pm 0.44)$ & $1.99( \pm 0.43)$ & $86 \mathrm{~b}$ & $203( \pm 17) b$ & $33( \pm 4) b c$ \\
\hline P. australis * 2013 & $3.8( \pm 0.43)$ & $1.74( \pm 0.14)$ & $62 \mathrm{a}$ & $268( \pm 5) c$ & $25( \pm 2) a b$ \\
\hline P. australis * 2014 & $3.81( \pm 0.3)$ & $1.9( \pm 0.12)$ & $97 \mathrm{~b}$ & $280( \pm 11) c$ & $17( \pm 1) \mathrm{a}$ \\
\hline P. virgatum $* 2013$ & $1.63( \pm 0.16)$ & $0.6( \pm 0.08)$ & $276 \mathrm{c}$ & $109( \pm 14) \mathrm{a}$ & $32( \pm 4) b c$ \\
\hline Effect & \multicolumn{5}{|c|}{ (n) } \\
\hline Year & 0.464 & 0.305 & 0.393 & 0.116 & 0.085 \\
\hline Species* Year & 0.737 & 0.642 & 0.017 & 0.019 & 0.044 \\
\hline Harvest* Year & 0.504 & 0.421 & 0.315 & 0.261 & 0.686 \\
\hline
\end{tabular}

* Denotes interaction between variables.

Table 4. Mean ( \pm standard error) plant characteristics for Phragmites australis, Panicum virgatum, and Miscanthus x giganteus 'Nagara', at three sites in Southwestern Ontario, Canada, harvested over two seasons in 2013 and $2014(n=6)$. Results of the three-way ANOVA also shown on Table 3. Means followed by the same letter in each column were not significantly different according to Tukey's range test $(p>0.05)$.

\begin{tabular}{|c|c|c|c|c|c|}
\hline Species and Harvest Time & Fresh Matter Yield & Dry Matter Yield & Stems $^{\dagger}$ & Height & Leaf \\
\hline & \multicolumn{2}{|c|}{$\ldots \ldots \mathrm{kg} \mathrm{m}^{-2} \ldots \ldots$} & - - Number $\mathrm{m}^{-2}$-- & $-\cdots--c m----$ & $\%$ of Total DM \\
\hline \multicolumn{6}{|c|}{ 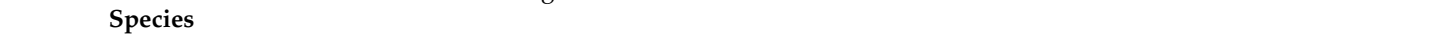 } \\
\hline M. x giganteus & $4.85( \pm 0.32) \mathrm{c}$ & $1.85( \pm 0.24) b$ & $93 \mathrm{~b}$ & $192( \pm 10) b$ & $37( \pm 2.4) b$ \\
\hline P. australis & $3.80( \pm 0.25) b$ & $1.82( \pm 0.09) b$ & $75 \mathrm{a}$ & $274( \pm 5.9) \mathrm{c}$ & $21( \pm 1.7)$ a \\
\hline P. virgatum & $1.56( \pm 0.12) \mathrm{a}$ & $0.59( \pm 0.05)$ a & $282 c$ & $103( \pm 8.3) \mathrm{a}$ & $34( \pm 2.6) b$ \\
\hline \multicolumn{6}{|l|}{ Harvest Time } \\
\hline July & $3.62( \pm 0.85)$ & $1.20( \pm 0.28) \mathrm{m}$ & 132 & $173( \pm 19.8) \mathrm{m}$ & $34( \pm 8.0) n$ \\
\hline October & $3.19( \pm 0.75)$ & $1.64( \pm 0.39) n$ & 120 & $205( \pm 15.4) n$ & $27( \pm 6.3) \mathrm{m}$ \\
\hline \multicolumn{6}{|l|}{ Species * Harvest Time } \\
\hline M. x giganteus * July & $4.79( \pm 0.40)$ & $1.28( \pm 0.15) x y$ & 106 & $166( \pm 7.9) \times$ & $38( \pm 2.8)$ \\
\hline M. x giganteus * October & $4.91( \pm 0.54)$ & $2.43( \pm 0.32) \mathrm{w}$ & 82 & $217( \pm 10.7) \mathrm{w}$ & $35( \pm 4.0)$ \\
\hline P. australis * July & $4.34( \pm 0.38)$ & $1.85( \pm 0.16) \mathrm{wx}$ & 61 & $274.5( \pm 8.1) \mathrm{v}$ & $22( \pm 2.2)$ \\
\hline P. australis * October & $3.27( \pm 0.12)$ & $1.80( \pm 0.10) \mathrm{wx}$ & 93 & $272.5( \pm 9.5) \mathrm{v}$ & $19( \pm 2.5)$ \\
\hline P. virgatum * July & $1.75( \pm 0.15)$ & $0.49( \pm 0.06) \mathrm{z}$ & 273 & $79.7( \pm 6.8) \mathrm{z}$ & $41( \pm 2.8)$ \\
\hline P. virgatum * October & $1.38( \pm 0.15)$ & $0.69( \pm 0.07) \mathrm{yz}$ & 292 & $126( \pm 6.4) y$ & $27( \pm 1.7)$ \\
\hline Effect & & 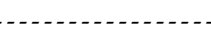 & - $p$ value - - - & $-\ldots-\ldots$ & \\
\hline Species & $<0.001$ & $<0.001$ & $<0.001$ & $<0.001$ & $<0.001$ \\
\hline Harvest Time & 0.120 & 0.003 & 0.283 & $<0.001$ & 0.002 \\
\hline Species * Harvest Time & 0.216 & 0.003 & 0.623 & $<0.001$ & 0.061 \\
\hline Species * Harvest * Year & 0.359 & 0.672 & 0.753 & 0.194 & 0.744 \\
\hline
\end{tabular}

${ }^{\dagger}$ Data was transformed using a logarithmic base 10 transformation. ${ }^{*}$ Denotes interaction between variables.

There was an interaction between species and year for stem count, plant height, and percent leaf matter (data not shown). No other effects or interactions were found for year. Phragmites australis stem count was 33\% higher in 2013 compared to 2014, while there was no difference among years for P. virgatum or M. x giganteus. There was no difference in Panicum virgatum, P. australis and $M$. $\mathrm{x}$ giganteus in plant height or in percent leaf matter, in 2013 and 2014 (Table 3). Phragmites australis had the lowest percentage of leaf matter, and all species had lower percentages of leaf matter in October compared with July (Table 2). Stems of P. australis that had overwintered from the previous year accounted for $14.5 \pm 4.8 \%$ of the fresh matter biomass (data not shown). Panicum virgatum had the shortest average plant height, followed by M. x giganteus and P. australis, at $103 \pm 8.3,192 \pm 10$, and $274 \pm 5.9 \mathrm{~cm}$, respectively. Correspondingly, $P$. virgatum had the highest stem count, followed by $M$. $\mathrm{x}$ giganteus and $P$. australis, at 283,93 , and 75 stems per $\mathrm{m}^{-2}$, respectively (Table 4). 
There were differences between the species and harvest times for some chemical constituents (Table 2). Specifically, P. australis biomass had lower concentrations of hemicellulose than both other perennial grasses, percent DM was highest in $M . \mathrm{x}$ giganteus and not different than P. virgatum, and protein was lowest for $P$. virgatum. In terms of main effects, there was an increase of $16.2 \%$ in the overall DM content between the July and October harvests. There was a significant reduction in overall protein content, from $90.8( \pm 11.2) \mathrm{g} \mathrm{kg}^{-1} \mathrm{DM}$ in July to $50.5( \pm 5.5) \mathrm{g} \mathrm{kg}^{-1} \mathrm{DM}$ in October. Nitrogen concentration varied by species and harvest time, with $M$. x giganteus dropping from $17.9 \pm 0.9$ to $7.4 \pm 0.9 \mathrm{~g} \mathrm{~kg}^{-1}$ from July to October, respectively, but no change in other species (Supplementary Materials).

Though it could not be included in the statistical analysis, due to lack of replication, Z. mays silage data tended to be different than those of the perennial grasses. Specifically, compared to other treatments in our study, Z. mays silage had: lower amounts of cellulose, hemicellulose, lignin, and DM.

\subsection{Biological Methane Potential Assay}

The mean $\mathrm{pH}$ of digestate-grass solutions did not vary between experimental groups $(p=0.641)$, but it did change over the duration of the experiment $(p<0.001)$ : $\mathrm{pH}$ was initially $7.9 \pm 0.04$, and it was reduced to $7.5( \pm 0.02)$ by the end of the study. The digestate-only control maintained a constant $\mathrm{pH}$ of $8.1 \pm 0.1(p=0.965)$. The mean electrical conductivity for mixtures with perennial grass samples was $17.12 \pm 0.32 \mathrm{mmhos} \mathrm{cm}^{-1}$ and did not vary between experimental groups $(p=0.638)$ or during the duration of the experiment $(p=0.163)$. After 21 days of each run, the methane production rates ranged from 1.1 to $1.5 \mathrm{~mL} \mathrm{CH}_{4} \mathrm{~g}^{-1} \mathrm{VS}_{\text {day }}{ }^{-1}$.

Corn silage yields were $337.0 \pm 7.2,347.4 \pm 6.0$, and $324.6 \pm 1.7 \mathrm{~L} \mathrm{CH}_{4} \mathrm{~kg}^{-1}$ VS for BMP runs 1,2 , and 3, respectively, with no differences found among runs $(p=0.089)$. Methane yield varied among perennial grass species on a DM basis $(p=0.049)$, with $P$. australis having lower yields than M.x giganteus and P. virgatum (Table 5). Harvest time also affected methane yields, with the July-harvest samples yielding greater quantities of methane than the October-harvest samples, with differences of 26,23 , and $6 \%$, based on VS, DM, and FM, respectively (Table 5). There was no difference between harvest-time for methane yields per $\mathrm{m}^{2}$, percent methane, or volatile solids reduction. There was a significant interaction between species and harvest time for methane yield per area harvested (Table 5). The methane yield per area of P. virgatum showed no difference between July and October harvest times, whereas P. australis yields decreased, and M. $\mathrm{x}$ giganteus yields increased (corresponding to a biomass yield increase, Table 4).

Biomass yield had a greater impact on methane yield per-area than it did on methane yield per kg VS of feedstock. While overall P. virgatum had the highest methane yield on a DM basis $\left(114.5 \pm 11.3 \mathrm{~L} \mathrm{CH} 4 \mathrm{~kg}^{-1} \mathrm{DM}\right)$, it had the lowest per-area yield $\left(116.7 \pm 12.4 \mathrm{~L} \mathrm{CH}_{4} \mathrm{~m}^{-2}\right)$, at less than half of the next closest species (P. australis, $249.9 \pm 33.3 \mathrm{~L} \mathrm{CH}_{4} \mathrm{~m}^{-2}$ ) (Table 5). Fall-harvested $M . \mathrm{x}$ giganteus had the highest potential $\mathrm{L} \mathrm{CH}_{4}$ yield $\mathrm{m}^{-2}$ (371.4 \pm 19.8$)$ compared to the other perennial species (Table 5). However, the per-area yields of all perennial species were much less than those of Z. mays, which had potential for $581.2 \pm 7.5 \mathrm{~L} \mathrm{CH}_{4}$ yield $\mathrm{m}^{-2}$. The same was true for $\mathrm{Z}$. mays yields in terms of VS, DM, or FM (Table 5). 
Table 5. Mean methane yields from mesophilic bench-top reactors for Miscanthus x giganteus 'Nagara', Panicum virgatum, and Phragmites australis when harvested in July or October $(n=3)$. Means for corn silage (Zea mays) displayed $(n=9)$, but not included in the two-way ANOVA. Means followed by the same letter in each column were not significantly different according to Tukey's range test $(p>0.05)$. Methane yield presented on volatile solids, dry matter, and fresh matter basis for ease of use by biogas facility operators.

\begin{tabular}{|c|c|c|c|c|c|}
\hline Species and Harvest Time & $\mathrm{LCH}_{4} \mathrm{~kg}^{-1} \mathrm{VS}^{+}$ & $\mathrm{LCH}_{4} \mathrm{~kg}^{-1} \mathrm{DM}^{\ddagger}$ & $\mathrm{LCH}_{4} \mathrm{~kg}^{-1} \mathrm{FM}^{\S}$ & $\mathrm{L} \mathrm{CH}_{4} \mathrm{~m}^{-2}$ & Methane (\%) \\
\hline \multicolumn{6}{|l|}{ Species } \\
\hline M. x giganteus & $198.6( \pm 16)$ & $175.8( \pm 12.3) b$ & $69.2( \pm 5)$ & $339.0( \pm 27.3) \mathrm{c}$ & $72.3( \pm 7.1)$ \\
\hline P. australis & $140.0( \pm 16.1)$ & $114.5( \pm 11.3)$ a & $67.8( \pm 6.4)$ & $249.9( \pm 33.3) b$ & $72.8( \pm 1.3)$ \\
\hline P. virgatum & $173.3( \pm 13.4)$ & $159.2( \pm 12.4) b$ & $72.4( \pm 5.4)$ & $116.7( \pm 12.4)$ a & $66.5( \pm 2.3)$ \\
\hline Z. mays & $334.9( \pm 4.3)$ & $314.1( \pm 4.1)$ & $123.5( \pm 1.6)$ & $497.5( \pm 6.4)$ & $75.6( \pm 3.9)$ \\
\hline \multicolumn{6}{|l|}{ Harvest Time } \\
\hline July & $196.2( \pm 2.8)$ y & $169.1( \pm 2.8) \mathrm{y}$ & $72.1( \pm 1.1) y$ & $247.5( \pm 4.4)$ & $69.7( \pm 4.3)$ \\
\hline October & $145.1( \pm 12.2) \mathrm{z}$ & $130.6( \pm 11.9) \mathrm{z}$ & $67.5( \pm 4.8) \mathrm{z}$ & $222.9( \pm 4.5)$ & $71.3( \pm 2.8)$ \\
\hline \multicolumn{6}{|l|}{ Species * Harvest Time } \\
\hline M. x giganteus * July & $229.8( \pm 15.2)$ & $198.6( \pm 13.2)$ & $54.0( \pm 3.6)$ & $253.2( \pm 16.8) x$ & $77.4( \pm 9.3)$ \\
\hline M. $\mathrm{x}$ giganteus * October & $167.5( \pm 8.9)$ & $153.0( \pm 8.2)$ & $75.5( \pm 4.0)$ & $371.4( \pm 19.8) \mathrm{w}$ & $68.7( \pm 5.8)$ \\
\hline P. australis* July & $172.4( \pm 15.3)$ & $136.4( \pm 12.1)$ & $58.2( \pm 5.2)$ & $251.7( \pm 22.3) x$ & $70.6( \pm 5.0)$ \\
\hline P. australis * October & $107.6( \pm 3.9)$ & $92.6( \pm 3.4)$ & $50.8( \pm 1.9)$ & $166.2( \pm 6.1) y$ & $75.9( \pm 5.2)$ \\
\hline P. virgatum* July & $186.5( \pm 9.4)$ & $172.2( \pm 8.7)$ & $48.5( \pm 2.5)$ & $83.6( \pm 4.2) \mathrm{z}$ & $63.0( \pm 3.4)$ \\
\hline P. virgatum $*$ October & $160.1( \pm 25.2)$ & $146.2( \pm 23.0)$ & $75.3( \pm 11.9)$ & $101.2( \pm 15.9) \mathrm{z}$ & $71.2( \pm 4.6)$ \\
\hline \multicolumn{6}{|l|}{ Interactions } \\
\hline Species & 0.052 & 0.027 & 0.348 & 0.001 & 0.194 \\
\hline Harvest Time & 0.033 & 0.049 & 0.046 & 0.099 & 0.869 \\
\hline Run & 0.824 & 0.829 & 0.954 & 0.813 & NA \\
\hline Harvest Time * Run & 0.656 & 0.632 & 0.771 & 0.808 & 0.521 \\
\hline Species* Run & 0.549 & 0.554 & 0.579 & 0.245 & 0.965 \\
\hline Species * Harvest Time & 0.513 & 0.787 & 0.138 & 0.006 & 0.803 \\
\hline
\end{tabular}

NA: Not available, measurements for first run not taken. ${ }^{\dagger}$ VS: Volatile solids. ${ }^{\ddagger}$ DM: Dry matter. ${ }^{\S}$ FM: Fresh matter.

* Denotes interaction between variables.

\section{Discussion}

\subsection{Harvest and Biomass Yields}

We did not observe any regrowth between the July and October harvest times for any of the species tested. This may have been due to the cutting height used, which left only $10 \mathrm{~cm}$ of stubble. Others have recommended a stubble height of $20 \mathrm{~cm}$ for seasonal regrowth to occur in P. virgatum [6], or 25-30 cm in P. australis [25]. The lack of regrowth may have also been due to the harvest time-points that we selected, the shorter growing season at our experimental sites compared to studies conducted in the USA, or limited soil nitrogen [26]. Regrowth has been reported for P. australis [25] and P. virgatum [27], which resulted in a $25 \%$ increase in methane yield per unit area in the case of P. virgatum. For long-term stand health, Miscanthus is best managed with delayed-harvests, typically in the winter or spring after the growing season, allowing time between the end of the growing season and harvest [28]. Therefore, while more research is required to determine the precise variables that prevented regrowth in our study, such lack of regrowth may be seen as a possible advantage for using and controlling wild P. australis stands.

The M. x giganteus biomass yields of $1.28 \pm 0.15$ to $2.43 \pm 0.32 \mathrm{~kg} \mathrm{DM} \mathrm{m}^{-2}$ found in this study were similar to those reported in Illinois (1.4 to $4.4 \mathrm{~kg} \mathrm{DM} \mathrm{m}^{-2}$ ) [29]. Panicum virgatum yields in our study of 0.49 to $0.69 \mathrm{~kg} \mathrm{DM} \mathrm{m}^{-2}$ were similar to those found in other studies in eastern Canada, ranging from 0.40 to $1.26 \mathrm{~kg} \mathrm{DM} \mathrm{m}^{-2}[27,30]$. Phragmites australis has been shown to have highly variable yields depending on location, ranging from 0.7 to $4.0 \mathrm{~kg} \mathrm{DM} \mathrm{m}^{-2}$ at three Scottish sites [15]. In our study, P. australis yields fell within this range (mean $1.83 \mathrm{~kg} \mathrm{DM} \mathrm{m}^{-2}$ ). Results for studies on P. australis in Scotland [15] and Sweden [31] had maximum DM yields in late summer (August and September), though there was no increase in yield between the July and October harvest dates in our study. The stems that remained standing from the previous year increased the initial biomass 
measured in our study, possibly accounting for why initial biomass yield was comparable to the later harvest date. Phragmites australis stems which visually appeared to have overwintered accounted for $14.5 \pm 4.8 \%$ of the FM biomass in the samples of our study, which possibly translates to a much greater percentage on a DM basis, since these stems appeared to be extremely dry. However, separate DM measurements were not taken for seasonal and overwintered stems, due to the constraints of our experimental design.

The optimal DM content for material to be ensiled is between 28 and 35\% [32]. At the time of July harvests, M. x giganteus and P. virgatum were at the low end of this range (27.2 \pm 3.2 and $28.2 \pm 2.1 \% \mathrm{DM}$, respectively), and P. australis was drier at $42.7 \pm 1.7 \%$ (Table 2). Thus, the higher moisture contents of all species in our study in the July harvest relative to the October harvest suggest that the optimal time for harvesting these species for silage purposes in Ontario may be at some point in early or midsummer (e.g., June).

Panicum virgatum had different characteristics compared to the other two perennial grasses, having the shortest stems, highest stand density, and the leafiest biomass (Table 4). Panicum virgatum had the lowest protein concentration of the plants in our study (Table 2). The data for the aforementioned variables we measured in P. virgatum were consistent with the literature [6], suggesting that $P$. virgatum may be a poor choice as a model organism for perennial grass biomass species, as it is not necessarily representative of other tall perennial grasses.

Both the harvest times of $P$. australis had lower concentrations of hemicellulose than the other species, ranging from $238.4 \pm 2.9$ to $252 \pm 3.0 \mathrm{~g} \mathrm{~kg}^{-1}$ of DM (Table 2). These values were lower than the only other reported hemicellulose value for P. australis ( $320 \mathrm{~g} \mathrm{~kg}^{-1}$ of DM) [33]. This difference in hemicellulose content could be due to differences in harvest timing and/or biogeographic and natural variation, as the previous study was from Finland (harvest timing not reported). The observed trend of P. australis protein concentrations (Table 2) being higher in samples taken in the summer than in the fall was likely due to shedding leaves and translocation of nutrients into rhizomes during senescence [31].

The protein concentrations of the perennial grasses in our study were lower in July compared to the October harvest time, at $90.8 \pm 11.2$ and $50.5 \pm 5.5 \mathrm{~g} \mathrm{~kg}^{-1} \mathrm{DM}$, respectively (Table 2). Protein concentrations also varied by species, with P. virgatum having the least, at $43.8 \pm 4.9 \mathrm{~g} \mathrm{~kg}^{-1}$ $\mathrm{DM}$, and M. x giganteus and P. australis having $79.2 \pm 15.2$ and $88.9 \pm 11.7 \mathrm{~g} \mathrm{~kg}^{-1} \mathrm{DM}$, respectively. A link has been shown between higher protein and higher methane yields [34], suggesting that the July harvest time could be a more productive option than the October harvest time in terms of methane production. However, there was no relationship between protein concentration and methane yield in this study, which was possibly due to the limited scope of the chemical analysis.

Given the design of the study, specifically the limited scope of chemical analysis (with data only from 2013 samples) and the lack of growing species side-by-side, the conclusions that could be drawn about the relationships between field data and chemical constituents of biomass need to be carefully considered. However, when combining all species together, there was a positive linear relationship between plant height and lignin content (lignin $=0.28$ (height) $+31.37 ; \mathrm{R}^{2}=0.36$, $p=0.008$ ). This correlation makes biological sense, given that the primary function of lignin is structural support [35], however a more in-depth investigation of the relationships between plant height, lignin, and BMP should be undertaken, as plant height is a very easily-measured characteristic. Phragmites australis was taller than the other species in our study, and regularly contained year-old stems at harvest (more than any other species in this study); both of these factors likely contributed to P. australis having the highest lignin content of the species that we studied.

The biology and agronomy of Z. mays are considerably different compared to the perennial grasses investigated in this study, and this was reflected in its chemical composition, as it was regularly at the extreme ends of the ranges that we measured. In addition, there were large differences between Z. mays and the perennial grasses in terms of methane potential. 


\subsection{Biological Methane Potential}

It is often difficult to compare methane yields among studies, due to differences in plant species, cultivars geography, stand type, and digestion parameters (including retention time, reactor size, reactor style, and microbial environment). However, previous studies have reported similar methane yields for certain perennial grass species. For untreated, late-harvested Miscanthus spp. methane yields between 80 to $200 \mathrm{~L} \mathrm{CH}_{4} \mathrm{~kg}^{-1}$ VS have been reported [36,37], and our data varied seasonally between $167.5 \pm 8.9$ and $229.8 \pm 15.2 \mathrm{~L} \mathrm{CH}_{4} \mathrm{~kg}^{-1}$ VS. Based on the decrease in BMP between harvest times we observed in this study, the lower BMP reported by others [36,37] may have been due to the time at which Miscanthus spp. was harvested (December). Panicum virgatum yields have been reported to range from 190 to $310 \mathrm{~L} \mathrm{CH}_{4} \mathrm{~kg}^{-1}$ VS [27,30], which was slightly higher than the methane yields found in this study. The higher P. virgatum yields in the previous studies compared to ours were likely due to ensiling of grass samples prior to digestion, and longer digestion periods of 60 days compared with 21 days $[27,30]$.. Methane yields reported for P. australis range widely from 34 to $220 \mathrm{~L} \mathrm{CH}_{4} \mathrm{~kg}^{-1}$ VS [16,33], with our results from this study at the higher end of the range. This aforementioned result of comparably high methane yields could be due to differences in biomass quality, or digestion parameters and conditions.

Zea mays silage is the most widely used purpose-grown biogas feedstock, due to its high methane potential, typically yielding from 289 to $390 \mathrm{~L} \mathrm{CH}_{4} \mathrm{~kg}^{-1}$ VS or 589.7 to $877.8 \mathrm{~L} \mathrm{CH}_{4} \mathrm{~m}^{-2}$ [38,39]. Zea mays silage yields in this study were $334.9 \pm 4.3 \mathrm{~L} \mathrm{CH}_{4} \mathrm{~kg}^{-1} \mathrm{VS}$, falling close to the center of this range. Digestate inoculum used in the aforementioned studies with higher BMP possibly had microbial communities that were better acclimated to digesting $Z$. mays silage, as the digestate came from commercial reactors utilizing corn silage as a primary feedstock, while the inoculum used in our study did not. Considering the similarity of $Z$. mays silage BMP results in this study to those in other studies, the BMP assay used in this study can be said to have a typical methane yield performance.

There is a shortage of data for methane yields per unit area of harvested biomass. Summer methane yields of $260 \pm 33$ and fall yields of $176 \pm 26 \mathrm{~L} \mathrm{CH}_{4} \mathrm{~m}^{-2}$ have previously been reported for P. virgatum grown in Eastern Canada [30], which was considerably higher than yields reported in this study. This aforementioned discrepancy between the results is likely due to differences in BMP methodology. Specifically, Massé et al. [30] used a larger digestion scale (30 L), a different feedstock mixture, and recirculated mixing as opposed to mechanical stirring. Methane by area comparisons for M. x giganteus and P. australis could not be made due to lack of available data.

Like our study, other research has shown that greater biomass yields resulted in greater methane per-area yields, despite declines in quality and digestibility of biomass [40,41]. Within each of the species we studied, this aforementioned rule of biomass yield having a greater impact on methane per area feedstock harvested than biomass quality was true. However, this rule did not remain valid when comparing between species. Both summer and fall-harvested P. australis yielded greater amounts of DM per area than summer-harvested $M$. x giganteus, but the quality of the material harvested was such that overall methane yields per area were highest for fall-harvested M. x giganteus. Based on the harvest times evaluated in this study, the greatest methane yield per area harvested of P. australis, P. virgatum, and M. x giganteus can be achieved at time of maximum biomass yield.

As other authors have observed [28], the biomass yields of grasses (M. x giganteus and P. virgatum) increased over time, though methane yield per unit feedstock (in terms of either VS or DM contents) decreased as the grass matured. This trade-off between biomass yield and methane yield is important to consider when screening other species for biomass applications. If the primary goal is to have the highest possible methane yield per area of perennial grass biomass harvested, then feedstock should be harvested at the time of maximum biomass yield. This assertion is likely even more important if a pretreatment method (e.g., enzymatic, weak acid, steam explosion, etc.) is used on biomass to reduce the recalcitrance of lignocellulose [42]. 


\subsection{Phragmites australis Disposal Using Anaerobic Digestion}

Phragmites australis control programs in Ontario, Canada, cost in the range of $\$ 660$ to $\$ 850$ (all prices in USD) $\mathrm{ha}^{-1}$ [43]. Here we have reported the methane potential of $P$. australis to be approximately $2500 \mathrm{~m}^{3} \mathrm{ha}^{-1}$. Assuming that there are $10.5 \mathrm{kWh}$ of energy per $\mathrm{m}^{3}$ methane and a $25 \%$ efficiency for converting methane to electrical energy in a combined heat and power engine, the electrical output would be $6562.5 \mathrm{kWh} \mathrm{ha}^{-1}$. In Ontario, electricity produced from biogas is valued at between $\$ 0.13$ and $\$ 0.20 \mathrm{kWh}^{-1}$, which would translate to a revenue of $\$ 826$ to $\$ 1292$. However, this simple calculation does not include harvesting, shipping, handling, or storage costs, and does not consider the opportunity cost of using $P$. australis as a feedstock instead of alternatives with higher methane yield. Similarly, it does not include the potential economic value of the heat generated during methane combustion.

The potential ecological risk from dissemination of invasive plant material (whole plants or pieces, seeds, rhizomes) should not be ignored. We have previously reported that there is a low risk of $P$. australis seed survival during anaerobic digestion, but harvesting and transportation of biomass would introduce new and uncontrolled pathways for dissemination [44]. The efficacy of $P$. australis control from harvesting may also be lesser than more comprehensive strategies, which include herbicide application and in situ biomass burning. A more comprehensive risk analysis is necessary before anaerobic digestion should be considered as a potential strategy for management of P. australis. However, it is likely that from an economic standpoint, the disposal of P. australis via anaerobic digestion would be more economically feasible than current control methods. The economic benefit could be further increased if methane yields were improved using pretreatment technologies as well.

\section{Conclusions}

Based on the results from this study, the best time to harvest P. australis, M. x giganteus, and $P$. virgatum in terms of reaching the maximum methane potential per unit feedstock would be in early summer. A harvest date before July, when the biomass has higher moisture content and protein concentrations, produces biomass that is more digestible and better suited for ensiling. However, in order to achieve maximum methane yield per area harvested, the biomass of these perennial grasses should be harvested at time of peak biomass yield (e.g., an October harvest time). Determining which scenario is optimal depends on the process involved (i.e., if the material needs to be ensiled and stored), and on local feedstock availability.

Wild stands of invasive P. australis have biomass yields that are similar to those of two biomass grasses that are currently grown in Southwestern Ontario: P. virgatum and M. x giganteus. While P. australis does not appear to be a desirable biogas feedstock, purely from a methane potential standpoint, disposal of this invasive plant using anaerobic digestion instead of current practices would have economic benefits. However, further research that comprehensively evaluates the economics and risks of $P$. australis disposal using anaerobic digestion is necessary before this strategy can be recommended.

Supplementary Materials: The following are available online at http:/ /www.mdpi.com/1996-1073/11/9/2198/ s1, Figure S1: Location of cultivated Miscanthus x giganteus (purple markers; $42^{\circ} 4.132^{\prime} \mathrm{N} 82^{\circ} 38.1^{\prime} \mathrm{W}^{\circ} 42^{\circ} 8.196^{\prime}$ $\mathrm{N} 82^{\circ} 38.406^{\prime} \mathrm{W}$ and $42^{\circ} 8.71^{\prime} \mathrm{N} 82^{\circ} 38.276^{\prime} \mathrm{W}$ ) and Panicum virgatum (green markers; $42^{\circ} 41.783^{\prime} \mathrm{N} 81^{\circ} 54.737^{\prime} \mathrm{W}$, $42^{\circ} 41.788^{\prime} \mathrm{N} 81^{\circ} 54.731^{\prime} \mathrm{W}$ and $42^{\circ} 37.629^{\prime} \mathrm{N} 81^{\circ} 59.897^{\prime} \mathrm{W}$ ) biomass, as well as wild stands of Phragmites australis (red markers; $42^{\circ} 33.368^{\prime} \mathrm{N} 82^{\circ} 31.178^{\prime} \mathrm{W}, 42^{\circ} 33.617^{\prime} \mathrm{N} 82^{\circ} 31.17^{\prime} \mathrm{W}$ and $42^{\circ} 19.904^{\prime} \mathrm{N} 82^{\circ} 24.576^{\prime} \mathrm{W}$ ) used in this experiment conducted in southwestern Ontario. Striped markers denote locations of the samples used in the biological methane potential analysis, Table S1: Mean ( \pm standard error) nutrient concentrations in Phragmites australis, Panicum virgatum, and Miscanthus x giganteus $(n=3)$ and Zea mays silage $(n=1)$ during July and October harvests for 2013 samples. Means followed by the same letter in each coloumn were not significantly different according to Tukey's range test $(p>0.05)$. Zea mays was not analyzed due to lack of replication, Table S2: Mean nutrient concentrations in Phragmites australis, Panicum virgatum, and Miscanthus x giganteus $(n=3)$ and Zea mays silage $(n=1)$ during summer and fall harvests for 2013 samples. Zea mays was not analyzed due to lack of replication. 
Author Contributions: Conceptualization, K.B. and B.H.G.; Methodology, K.B., D.E.R., L.L.V.E., P.H.S. and B.H.G.; Formal Analysis, K.B., D.E.R. and B.H.G., Writing-Original Draft Preparation, K.B. and B.H.G., Writing-Review and Editing, K.B., M.M. and B.H.G., Supervision, D.E.R., L.L.V.E., P.H.S. and B.H.G., Project Administration and Funding Acquisition, B.H.G.

Funding: This research was funded by was provided by the Natural Sciences and Engineering Research Council of Canada (grant 400806), the Agricultural Adaptation Council (AAC), and the University of Guelph Centre for Agricultural Renewable Energy and Sustainability.

Acknowledgments: Research contributions from student research assistants Pauline Halder, Steven Harvey, Colin Little, Emilie Philippe, Ian Prins, and Laura Van Vliet are gratefully acknowledged. We wish to thank Kimberly VanOverloop for technical assistance and provision of digestate materials. We also thank the Ontario Soil and Crop Improvement Association for their guidance in the early stages of this project. This research would not have been possible without kindly donated P. australis from Graham Hoogterp of Tahgahoning Enterprises Inc., P. virgatum from Rob Buchanan of Ontario NativeScape, and Miscanthus from the late Dean Tiessen of New Energy Farms.

Conflicts of Interest: The authors declare no conflict of interest.

\section{References}

1. Biogas Association. Interactive Map. Available online: https://www.biogasassociation.ca/ (accessed on 21 August2018).

2. Frigon, J.C.; Roy, C.; Guiot, S.R. Anaerobic co-digestion of dairy manure with mulched switchgrass for improvement of the methane yield. Bioproc. Biosyst. Eng. 2012, 35, 341-349. [CrossRef] [PubMed]

3. Grieder, C.; Dhillon, B.; Schipprack, W.; Melchinger, A. Breeding maize as biogas substrate in Central Europe: I. Quantitative-genetic parameters for testcross performance. Theor. Appl. Genet. 2012, 124, 971-980. [CrossRef] [PubMed]

4. Wang, X.; Zhang, L.; Xi, B.; Sun, W.; Xia, X.; Zhu, C.; He, X.; Li, M.; Yang, T.; Wang, P.; et al. Biogas production improvement and $\mathrm{C} / \mathrm{N}$ control by natural clinoptilolite addition into anaerobic co-digestion of Phragmites australis, feces and kitchen waste. Bioresour. Technol. 2015, 180, 192-199. [CrossRef] [PubMed]

5. McLaughlin, S.B.; Adams Kszos, L. Development of switchgrass (Panicum virgatum) as a bioenergy feedstock in the United States. Biomass Bioenergy 2005, 28, 515-535. [CrossRef]

6. Parrish, D.J.; Fike, J.H. The Biology and Agronomy of Switchgrass for Biofuels. Crit. Rev. Plant Sci. 2005, 24, 423-459. [CrossRef]

7. Atkinson, C.J. Establishing perennial grass energy crops in the UK: A review of current propagation options for Miscanthus. Biomass Bioenergy 2009, 33, 752-759. [CrossRef]

8. Mason, W.; Lachance, L. Effects of Initial Harvest Date on Dry Matter Yield, in Vitro Dry Matter Digestibility and Protein in Timothy, Tall Fescue, Reed Canary Grass and Kentuck Bluegrass. Can. J. Plant Sci. 1983, 63, 675-685. [CrossRef]

9. Bourgeau-Chavez, L.L.; Kowalski, K.P.; Carlson Mazur, M.L.; Scarbrough, K.A.; Powell, R.B.; Brooks, C.N.; Huberty, B.; Jenkins, L.K.; Banda, E.C.; Galbraith, D.M.; et al. Mapping invasive Phragmites australis in the coastal Great Lakes with ALOS PALSAR satellite imagery for decision support. J. Great Lakes Res. 2013, 39 (Suppl. 1), 65-77. [CrossRef]

10. Murray-Hudson, M.; Mmopelwa, G. Phragmites australis reedbeds in the southern Okavango Delta, Botswana. Afr. J. Plant Sci. Biotech. 2011, 5, 16-20.

11. Sathitsuksanoh, N.; Zhu, Z.; Templeton, N.; Rollin, J.A.; Harvey, S.P.; Zhang, Y.H.P. Saccharification of a Potential Bioenergy Crop, Phragmites australis (Common Reed), by Lignocellulose Fractionation Followed by Enzymatic Hydrolysis at Decreased Cellulase Loadings. Ind. Eng. Chem. Res. 2009, 48, 6441-6447. [CrossRef]

12. Haslam, S.M. Phragmites-Communis Trin. J. Ecol. 1972, 60, 585-610. [CrossRef]

13. Mook, J.H.; Van Der Toorn, J. The influence of environmental factors and management on stands of Phragmites australis. II. Effects on yield and its relationships with shoot density. J. Appl. Ecol. 1982, 19, 501-517. [CrossRef]

14. Brix, H.; Sorrell, B.K.; Lorenzen, B. Are Phragmites-dominated wetlands a net source or net sink of greenhouse gases? Aquat. Bot. 2001, 69, 313-324. [CrossRef]

15. Ho, Y.B. Shoot development and production studies of Phragmites australis (Cav.) Trin. Ex Steudel in Scottish Lochs. Hydrobiologia 1979, 64, 215-222. [CrossRef] 
16. Risén, E.; Gregeby, E.; Tatarchenko, O.; Blidberg, E.; Malmström, M.E.; Welander, U.; Gröndahl, F. Assessment of biomethane production from maritime common reed. J. Clean. Prod. 2013, 53, 186-194. [CrossRef]

17. Fredriksson, H. Storskalig Sommarskörd av vass_Energiåtgång, Kostnader och flöDen av växtnäring för System med skörd och Efterföljande Behandling (Harvesting of Common Reed during Summer-Energy Consumption, Costs and Nutrient Flow for Systems Including Harvesting and Treatment); Examensarbete, Sveriges lantbruksuniversitet (SLU): Uppsala, Sweden, 2002.

18. Hansson, P.-A.; Fredriksson, H. Use of summer harvested common reed (Phragmites australis) as nutrient source for organic crop production in Sweden. Agric. Ecosyst. Environ. 2004, 102, 365-375. [CrossRef]

19. Vymazal, J. Plants used in constructed wetlands with horizontal subsurface flow: A review. Hydrobiologia 2011, 674, 133-156. [CrossRef]

20. Bagg, J. Pricing Corn Silage in 2014. Ontario Ministry of Agriculture Food Rural Affairs. 2014. Available online: http:/ / www.omafra.gov.on.ca/english/crops/field/news/croptalk/2014/ct-0914a7.htm (accessed on 30 July 2015).

21. Engloner, A.I. Structure, growth dynamics and biomass of reed (Phragmites australis) - A review. Flora Morphol. Distrib. Funct. Ecol. Plants 2009, 204, 331-346. [CrossRef]

22. Ragaglini, G.; Dragoni, F.; Simone, M.; Bonari, E. Suitability of giant reed (Arundo donax L.) for anaerobic digestion: Effect of harvest time and frequency on the biomethane yield potential. Bioresour. Technol. 2014, 152, 107-115. [CrossRef] [PubMed]

23. Rice, E.W.; Baird, R.B.; Eaton, A.D.; Slesceri, L.S. Standard Methods for the Examination of Water and Wastewater, 22th ed.; American Public Health Association; American Water Works Association; Water Environment Federation: Denver, CO, USA, 2012.

24. Jurado, E.; Gavala, H.N.; Skiadas, I.V. Enhancement of methane yield from wheat straw, miscanthus and willow using aqueous ammonia soaking. Environ. Technol. 2013, 34, 2069-2075. [CrossRef] [PubMed]

25. Karunaratne, S.; Asaeda, T.; Yutani, K. Shoot regrowth and age-specific rhizome storage dynamics of Phragmites australis subjected to summer harvesting. Ecol. Eng. 2004, 22, 99-111. [CrossRef]

26. Lewandowski, I.; Scurlock, J.M.O.; Lindvall, E.; Christou, M. The development and current status of perennial rhizomatous grasses as energy crops in the US and Europe. Biomass Bioenergy 2003, 25, 335-361. [CrossRef]

27. Massé, D.; Gilbert, Y.; Savoie, P.; Bélanger, G.; Parent, G.; Babineau, D. Methane yield from switchgrass and reed canarygrass grown in Eastern Canada. Bioresour. Technol. 2011, 102, 10286-10292. [CrossRef] [PubMed]

28. Clifton-brown, J.C.; Stampfl, P.F.; Jones, M.B. Miscanthus biomass production for energy in Europe and its potential contribution to decreasing fossil fuel carbon emissions. Glob. Chang. Biol. 2004, 10, 509-518. [CrossRef]

29. Heaton, E.A.; Dohleman, F.G.; Miguez, A.F.; Juvik, J.A.; Lozovaya, V.; Widholm, J.; Zabotina, O.A.; McIsaac, G.F.; David, M.B.; Voigt, T.B.; et al. Miscanthus: A Promising Biomass Crop; Jean-Claude, K., Michel, D., Eds.; Academic Press: Cambridge, MA, USA, 2010; Chapter 3, pp. 75-137.

30. Massé, D.; Gilbert, Y.; Savoie, P.; Bélanger, G.; Parent, G.; Babineau, D. Methane yield from switchgrass harvested at different stages of development in Eastern Canada. Bioresour. Technol. 2010, 101, 9536-9541. [CrossRef] [PubMed]

31. Granéli, W. Reed Phragmites australis (Cav.) Trin. ex Steudel as an energy source in Sweden. Biomass 1984, 4, 183-208. [CrossRef]

32. Mast, B.; Lemmer, A.; Oechsner, H.; Reinhardt-Hanisch, A.; Claupein, W.; Graeff-Hönninger, S. Methane yield potential of novel perennial biogas crops influenced by harvest date. Ind. Crops Prod. 2014, 58, 194-203. [CrossRef]

33. Jagadabhi, P.S.; Kaparaju, P.; Rintala, J. Two-stage anaerobic digestion of tomato, cucumber, common reed and grass silage in leach-bed reactors and upflow anaerobic sludge blanket reactors. Bioresour. Technol. 2011, 102, 4726-4733. [CrossRef] [PubMed]

34. Prochnow, A.; Heiermann, M.; Plöchl, M.; Linke, B.; Idler, C.; Amon, T.; Hobbs, P.J. Bioenergy from permanent grassland-A review: 1. Biogas. Bioresour. Technol. 2009, 100, 4931-4944. [CrossRef] [PubMed]

35. Hendriks, A.T.W.M.; Zeeman, G. Pretreatments to enhance the digestibility of lignocellulosic biomass. Bioresour. Technol. 2009, 100, 10-18. [CrossRef] [PubMed]

36. Menardo, S.; Bauer, A.; Theuretzbacher, F.; Piringer, G.; Nilsen, P.; Balsari, P.; Pavliska, O.; Amon, T. Biogas Production from Steam-Exploded Miscanthus and Utilization of Biogas Energy and $\mathrm{CO}_{2}$ in Greenhouses. Bioenergy Res. 2013, 6, 620-630. [CrossRef] 
37. Uellandahl, H.; Wang, G.; Moller, H.B.; Jorgensen, U.; Skiadas, I.V.; Gavala, H.N.; Ahring, B.K. Energy balance and cost-benefit analysis of biogas production from perennial energy crops pretreated by wet oxidation. Water Sci. Technol. 2008, 58, 1841-1847. [CrossRef] [PubMed]

38. Amon, T.; Amon, B.; Kryvoruchko, V.; Machmüller, A.; Hopfner-Sixt, K.; Bodiroza, V.; Hrbek, R.; Friedel, J.; Pötsch, E.; Wagentristl, H.; et al. Methane production through anaerobic digestion of various energy crops grown in sustainable crop rotations. Bioresour. Technol. 2007, 98, 3204-3212. [CrossRef] [PubMed]

39. Amon, T.; Amon, B.; Kryvoruchko, V.; Zollitsch, W.; Mayer, K.; Gruber, L. Biogas production from maize and dairy cattle manure-Influence of biomass composition on the methane yield. Agric. Ecosyst. Environ. 2007, 118, 173-182. [CrossRef]

40. Weiland, P. Biogas production: Current state and perspectives. Appl. Microbiol. Biotechnol. 2010, 85, 849-860. [CrossRef] [PubMed]

41. Jin, G.; Bierma, T.; Walker, P. Biogas production from switchgrass under experimental conditions simulating U.S. digester operations. J. Environ. Sci. Health Part A 2012, 47, 470-478. [CrossRef] [PubMed]

42. Kumari, D.; Singh, R. Pretreatment of lignocellulosic wastes for biofuel production: A critical review. Renew. Sustain. Energy Rev. 2018, 90, 877-891. [CrossRef]

43. Ontario Ministry of Natural Resources and Forestry. Ontario Invasive Species Strategic Plan. 2012. Available online: https:/ / www.ontario.ca/document/invasive-species-strategic-plan-2012 (accessed on 21 August 2018).

44. Baute, K.A.; Robinson, D.E.; Van Eerd, L.L.; Edson, M.; Sikkema, S.; Gilroyed, B.H. Survival of seeds from perennial biomass species during commercial-scale anaerobic digestion. Weed Sci. 2016, 56, 258-266. [CrossRef]

(C) 2018 by the authors. Licensee MDPI, Basel, Switzerland. This article is an open access article distributed under the terms and conditions of the Creative Commons Attribution (CC BY) license (http:/ / creativecommons.org/licenses/by/4.0/). 